\title{
LEROY AND MYRTLE SIMMONS, RECORD-BREAKING WINNIPEG BIRD BANDERS
}

\begin{abstract}
C. STUART HOUSTON and MARY I. HOUSTON, 863 University Drive, Saskatoon, SK S7N 0J8
\end{abstract}

A small and unassuming city lot sits across the street from the Little Seine River in the Winnipeg suburb of St. Vital. Here a two-storey home, augmented by large nest boxes for Wood Ducks and Eastern Screech-owls, was built by LeRoy (known to his friends as "Roy") Simmons in 1947. Apart from a transfer to Flin Flon, 1950-1953, with Western Grocers, 170 Egerton Road remained the residence of the Simmons until they died. From 1963 until early 1978 it was the bird-banding station of Roy Simmons (evening and weekends) (Fig. 1), but mainly of Myrtle Simmons (Fig. 2), who banded birds during Roy's working hours. As Myrtle said in her privately-published reminiscences, $A$ Love Story, "I sure had to learn a powerful lot about bird identification in a big hurry." Daughter Dawn did much of the banding. Myrtle kept the banding

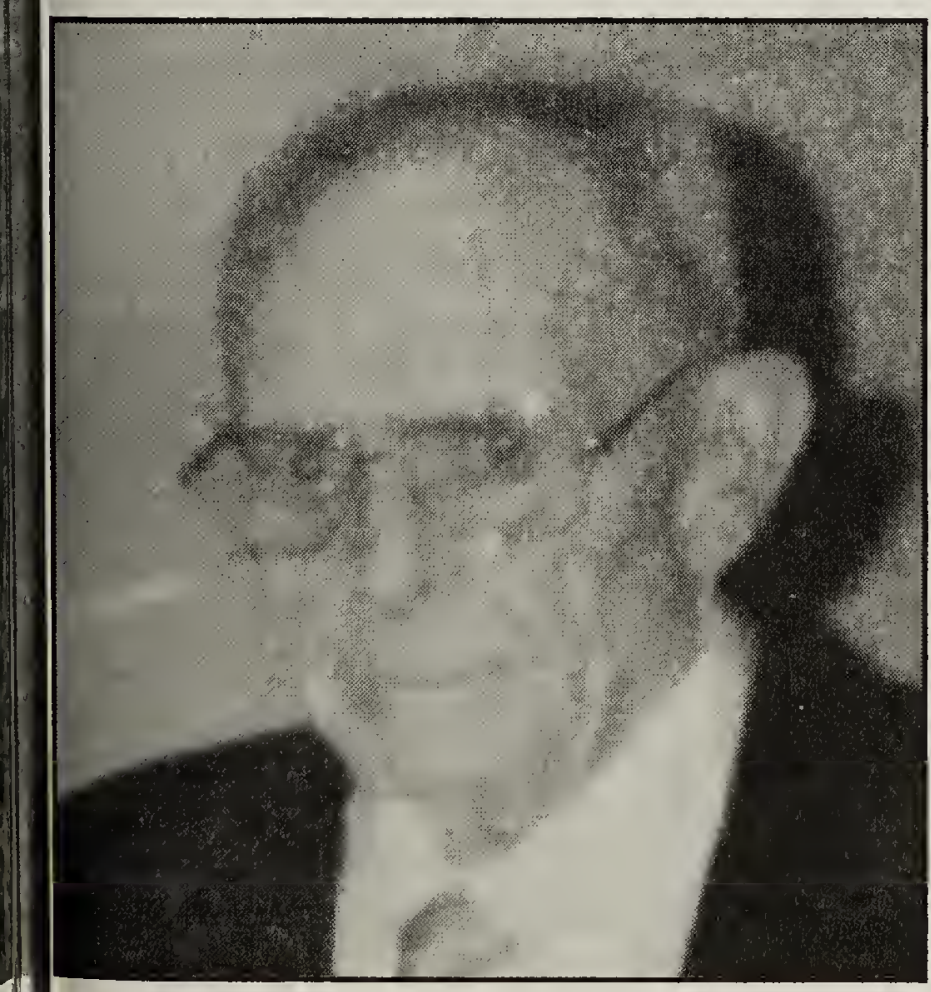

Figure 1. Leroy T. Simmons records and typed the reports in triplicate, until October 1977 when she became paralysed on one side from the rupture of an intracranial aneurysm. Without Myrtle's help, Roy ceased all banding in the spring of 1978 .

In migration and for most of the winter the lot was alive with birds, particularly finches, grosbeaks, and record-breaking numbers of redpolls and Pine Siskins. The feeders were loaded with seeds, suet and peanut butter. All birds were banded in the Simmons' yard except for 71 Black-crowned Night-herons banded near Oak Point on Lake Manitoba in 1967.

Roy Simmons was born in Winnipeg on 7 January 1912 and died there on 6 May 1996. His wife, Myrtle, née McArton, was born in Winnipeg on 20 June 1910

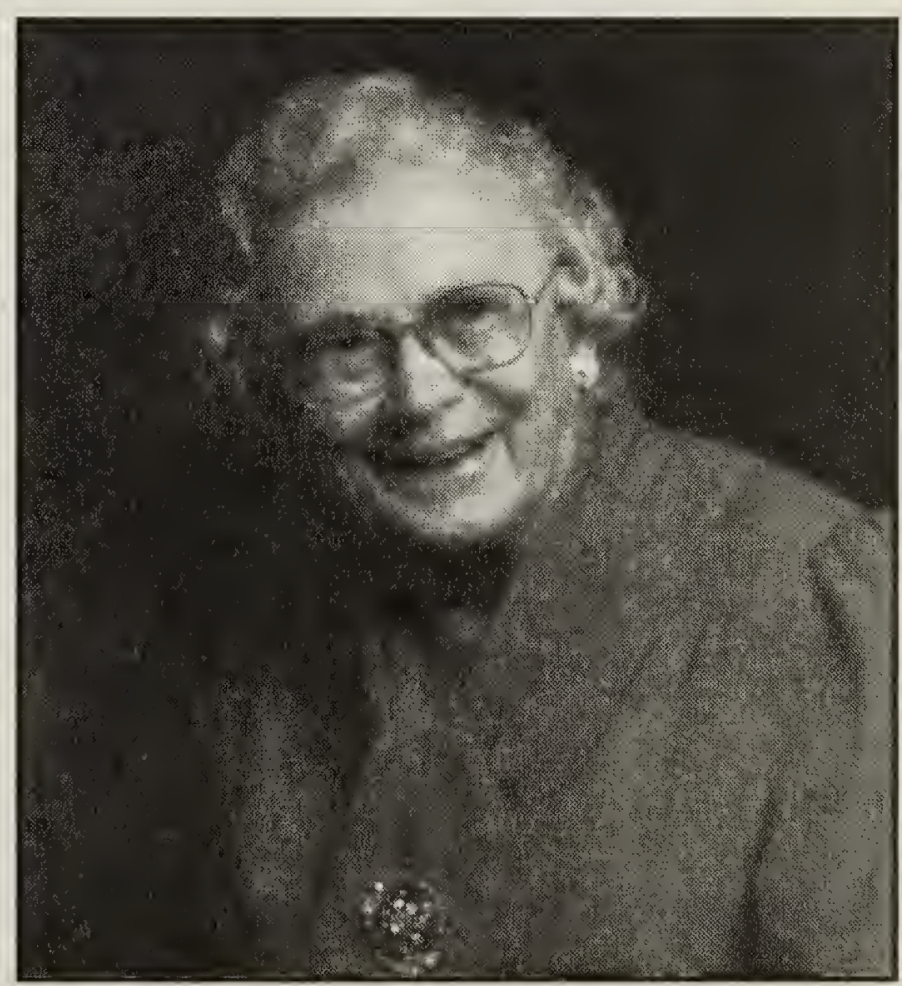

Figure 2. Myrtle Simmons 
and died there on 29 November 1995. Married on 13 July 1940, they first lived at Maymont, Saskatchewan, where Roy was a grain buyer for three years until he joined the Royal Canadian Air Force; he served in India in 1944 and 1945. I remember Mrs. Priestly's pleasure when she gave me Roy's article for typing: "A Sparrow Hawk Pet." (Blue Jay 1:21, 1943).

The Simmons together banded a remarkable 53,527 individuals of 67 species over 15 years. These included
22,504 Common Redpolls, at the time tops for the continent, 9,736 Pine Siskins, and 8,722 Purple Finches (Table 1). On a migration flyway, they caught birds banded elsewhere to the south and east of them, and these other banders retrapped a roughly equal number of Simmons-banded birds. Such records greatly augmented the chance finding of tiny bands on dead birds, and raised the results above those normally expected elsewhere in the western half of this continent.

Table 1 - Summary of Bird Banding Records by Leroy Simmons 1963-1978 (Species with recoveries or more than 50 individuals banded)

Species

Black-cr Night Heron

Am. Kestrel

Mourning Dove

Purple Martin

Blue Jay

Black-cap Chickadee

White-br Nuthatch

Swainson's Thrush

Am. Robin

Brown Thrasher

Bohemian Waxwing

Northern Shrike

Rose-br-Grosbeak

Fox Sparrow

Lincoln's Sparrow

White-thr Sparrow

White-cr Sparrow

Harris' Sparrow

Slate-col Junco

Common Grackle

Baltimore Oriole

Pine Grosbeak

Purple Finch

Red Crossbill

Common Redpoll

Hoary Redpoll

Pine Siskin

Am. Goldfinch

Evening Grosbeak

38 other species

Total

$\begin{array}{rrr}\text { \# Banded } & \text { \# Recov } & \% \text { Recov } \\ 71 & 0 & 0.0 \% \\ 2 & 1 & 50.0 \% \\ 44 & 1 & 2.3 \% \\ 74 & 0 & 0.0 \% \\ 907 & 34 & 3.7 \% \\ 454 & 3 & .07 \% \\ 144 & 1 & .07 \% \\ 67 & 0 & 0.0 \% \\ 99 & 3 & 3.0 \% \\ 16 & 3 & 18.8 \% \\ 66 & 0 & 0.0 \% \\ 16 & 1 & 6.3 \% \\ 295 & 4 & 1.4 \% \\ 418 & 1 & 0.2 \% \\ 116 & 0 & 0.0 \% \\ 1843 & 1 & 0.1 \% \\ 113 & 0 & 0.0 \% \\ 649 & 0 & 0.0 \% \\ 1864 & 1 & 0.1 \% \\ 59 & 10 & 16.9 \% \\ 48 & 1 & 2.1 \% \\ 42 & 1 & 2.4 \% \\ 8722 & 46 & 0.5 \% \\ 748 & 17 & 2.3 \% \\ 22504 & 26 & 0.1 \% \\ 830 & 0 & 0.0 \% \\ 9736 & 13 & 0.1 \% \\ 122 & 1 & 0.8 \% \\ 3127 & 69 & 2.2 \% \\ 331 & 0 & 0.0 \% \\ 53527 & 240 & 0.4 \% \\ & 0 & \end{array}$


Purple Finches banded by Roy and Myrtle, travelling south from Minnesota and Wisconsin down through states on both sides of the Mississippi River to Texas and Louisiana, demonstrated the migration pathway. In spring the finches went north and west through Saskatchewan and Alberta, one being killed by hitting a picture window at Smithers, British Columbia. The Simmons were fortunate in being able to recapture 23 Purple Finches banded elsewhere by other banders, including nine originally banded in Minnesota, six in Wisconsin, four in Michigan, two in lowa and one each in New Jersey and Tennessee. Another from Minnesota was found dead near their banding traps. The speed of migration is known for three finches banded in Minnesota: by Jane C. Olyphant at Lake Elmo, 605 $\mathrm{km}$ in 7 days; by James P. Ludwig near Bemidji, 320 km in 18 days; by L.S. Ryan near Little Falls, $470 \mathrm{~km}$ in 11 days. In turn, 21 of the Simmons finches were caught by other banders: 11 in Minnesota, 3 in lowa, 2 in Kansas, and one each in Wisconsin, Michigan, Illinois, Oklahoma and Arkansas; the latter finch covered $1555 \mathrm{~km}$ in 58 days (Fig. 3). Besides those caught in bander's traps or nets, eight hit windows, seven of them fatally, and four were shot, one as a scientific specimen. One of each species was killed by a highway vehicle, a dog, a cat, and ten were found dead without identified cause.

Fifteen of the 26 recoveries of 25 Common Redpolls were in the greater Winnipeg area; five hit windows, five were found dead, two were in traps, two killed by cats, and one was shot. Apart from one shot at Ridgeville, MB the month after it was banded, the nine distant birds were encountered in subsequent winters. Common Redpolls banded by the Simmons were caught by other banders in Minnesota (Bemidji at 24 mos. and Little Falls at 11 mos.),
Wisconsin (Chippewa Falls, see below), and Ontario (Toronto, same bird caught twice, at 23 and 24 mos.). A redpoll banded at St. Paul, MN, was found dead in Winnipeg. Single redpolls were found dead at Meadow Lake, SK at 11 mos., Arborg, MB at $1 \mathrm{y}$ and Oak Lake, MB, at $31 / 2$ y. and one was killed by a cat west of Gatzke, MN at 24 mos., and one hit a window at Hebron, Illinois at 20 mos. A nearly 5-year-old Common Redpoll, banded 30 March 1969 and retrapped at Chippewa Falls by bander C.A. Kemper on 18 March 1975, was the oldest of the 488 recoveries from 231,179 redpolls banded in North America until that time.

Of nine banded Pine Siskins caught at 170 Egerton Road, mainly in mist nets, five had been banded in Minnesota, and one each in North Carolina, Pennsylvania, Michigan and North Dakota. Two Pine Siskins banded near Little Falls, MN, made the $470 \mathrm{~km}$ trip in 13 and 15 days. Simmons-banded Pine Siskins were caught by other banders in Wisconsin, New York, Tennessee, North Carolina, Arkansas, Alabama, and one off course in California at a direct-line distance of $2405 \mathrm{~km}$. The numbers on one of these tiny bands was read by telescope at a feeder in Michigan. One hit a picture window, one was caught by a cat, and four died of unknown causes (Fig. 4).

Captures of 26 Evening Grosbeaks banded elsewhere again identified the west to east rather than north to south migration of this species: one from Quebec, two each from Connecticut and New York, one from Ohio, five from Wisconsin, and four from Minnesota. The Simmons also caught ten banded within greater Winnipeg by Harold Hosford and one by David Hatch. In turn, a slightly greater number (35) of their grosbeaks went elsewhere to be caught by other banders, 20 of them in 
Minnesota, 10 in Manitoba, and one each in Maine, New Jersey, Michigan, Wisconsin, and Alberta. An unusual movement occurred in 1966, when grosbeaks banded in Winnipeg on 8 March, 7, 19 and 25 April, and 5 May, all went south to be caught by Minnesota banders on 25, 29, 25, 27 and 26 May, respectively, in five different Minnesota localities, the last of these moving 130 $\mathrm{km}$ in 21 days. In early 1977, another took a similar southerly path from Winnipeg to Walker, Minnesota, $365 \mathrm{~km}$ in 13 days, 16 to 29 April. In addition to those reported by banders, six hit windows, two were shot and two caught in traps. Another 20 were found dead and four died of miscellaneous causes (Fig. 5). Their oldest Evening Grosbeak, at 12 years and $7 \frac{1}{2}$ months, banded 22 March 1966 and found dead of unknown causes in Michigan on 17 November 1978 , was nearly three years short of the oldest bird in the banding office files.

Of 10 recoveries (a very high rate of $16.9 \%$ ) of Common Grackle, four were shot and five simply "found dead" of unknown causes. One was killed by pesticide poisoning in Winnipeg at $71 / 2$ years. Among those shot, one was in Louisiana the same year as banded and another was in Minnesota the year after banding.

The Blue Jay recovery rate was relatively high $(3.7 \%)$. The two oldest were killed by a cat, and found dead, respectively, at 8 and $91 / 2$ years. Three moved south up the Red River valley, two to Minnesota (one was shot and one injured) and the third was found dead on the North Dakota side of the river four months after banding. A jay banded on 6 August was caught due to disease on 30 December and released near Victoria, Texas, after having travelled $2355 \mathrm{~km}$. This is supposedly a nonmigratory species! As well, the Simmons retrapped a Blue Jay banded in
Winnipeg by David Hatch.

Of 17 Red Crossbill recoveries $(2.3 \%)$, all were recovered within a year of banding, 16 in Manitoba and one that hit a window in Minnesota. A Mourning Dove was shot in South Dakota. Found dead elsewhere were a Harris' Sparrow in Nebraska, a White-throated Sparrow in Arkansas, a Slate-colored Junco in Minnesota, and an American Robin in lowa, all recovered within a year of banding. Rose-breasted Grosbeaks were recovered within greater Winnipeg at $1 \frac{1}{2}, 2 \frac{1}{2}$, and 5 years, and in North Dakota at $3 \frac{1}{2}$ years.

An American Kestrel was killed when hit by a car on the highway along Atikameg Lake, northeast of The Pas, $330 \mathrm{~km}$ NNW from the banding site. Two recoveries of Brown Thrasher, one at 31/2 years, and three of Black-capped Chickadee were of birds found dead in Winnipeg, as were one of two Harris' Sparrows and single recoveries of Pine Grosbeak, American Goldfinch, Northern Shrike and White-breasted Nuthatch. A Baltimore Oriole was brought in by a cat and a Fox Sparrow hit a window.

Roy's closest friend was the bird artist, Angus Shortt. During Roy's spare time, he made beautiful wood carvings and painted cartoon murals at the Children's Hospital. It is a credit to both Roy and Myrtle that, though both were reticent and not given to attending meetings, they were jointly presented with "The Wildlife Conservation Award" at a luncheon in the Manitoba Legislative Building in November 1986. Two years later the Manitoba Naturalists Society awarded Roy an honourary membership. Though the Simmons were too modest to publish their results, their achievements are unparalleled among western Canadian banders. 


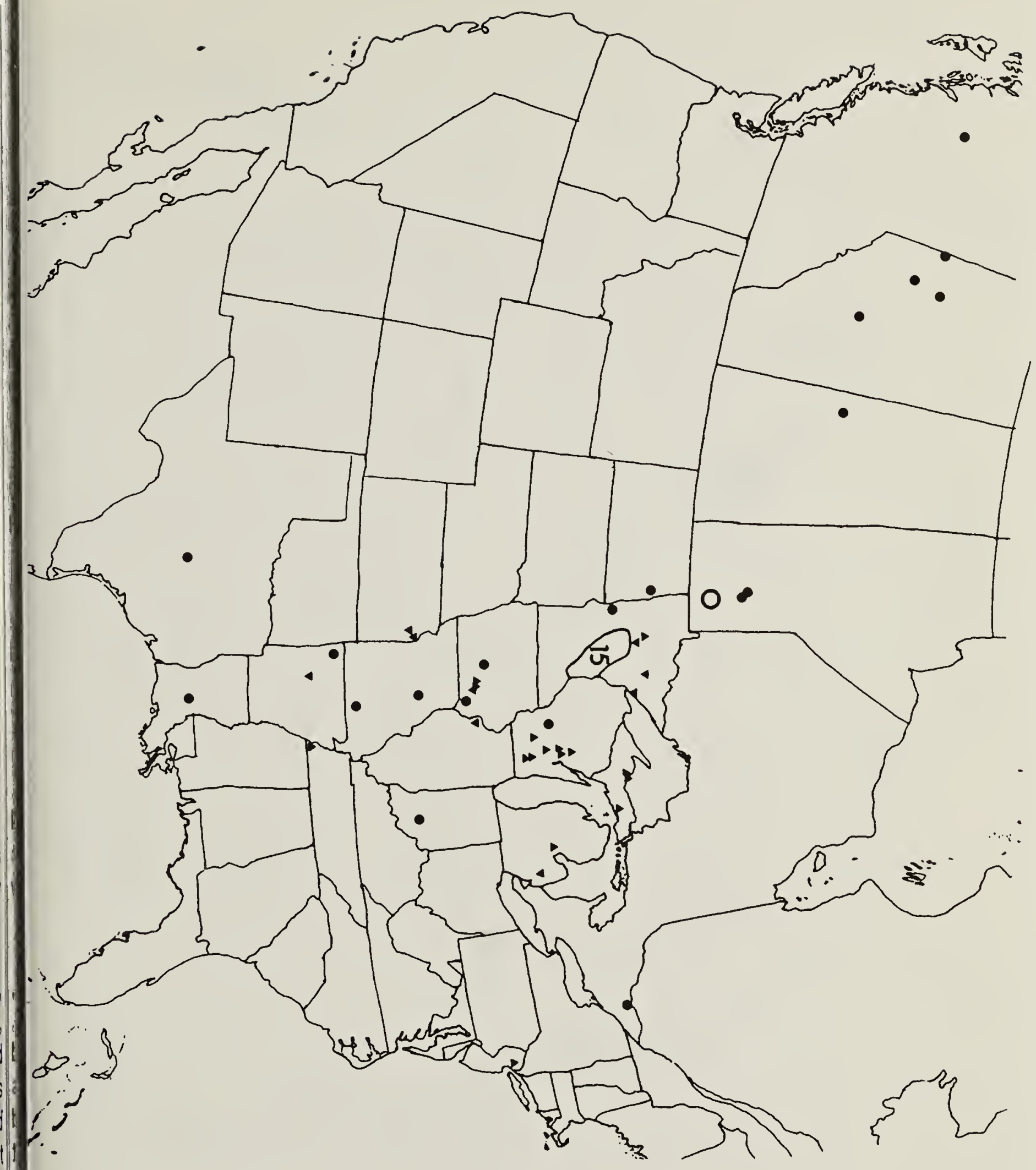

Figure 3. Purple Finch encounters. The open circle O marks Winnipeg. Closed circles - represent recoveries of finches found dead. Upright triangles $\Delta$ represent sites of other banders whose birds were recaught in Winnipeg. Inverted triangles Vrepresent finches banded in Winnipeg and retrapped elsewhere by other banders. There were 15 encounters, close together, within east-central Minnesota. Finches spread northwest after they reach Winnipeg. 


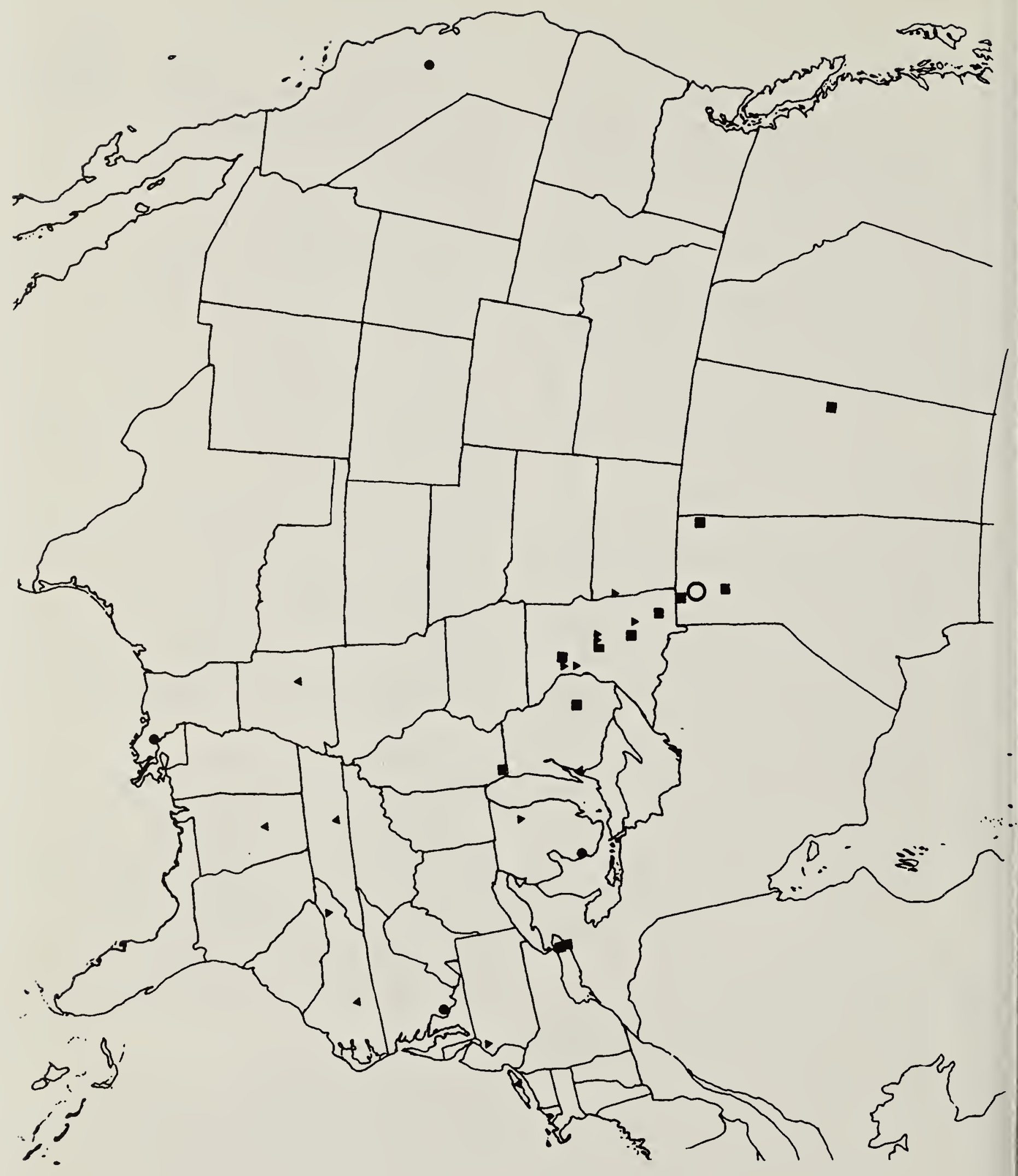

Figure 4. Common Redpoll encounters. Squares 1 , south almost to Chicago anc east to Toronto). Pine Siskin encounters, circles $\bullet$. Upright triangles $\Delta$ represen Pine Siskins banded elsewhere and retrapped in Winnipeg; inverted triangles Vrepresent Pine Siskins banded in Winnipeg by Simmons and recovered elsewhere. 


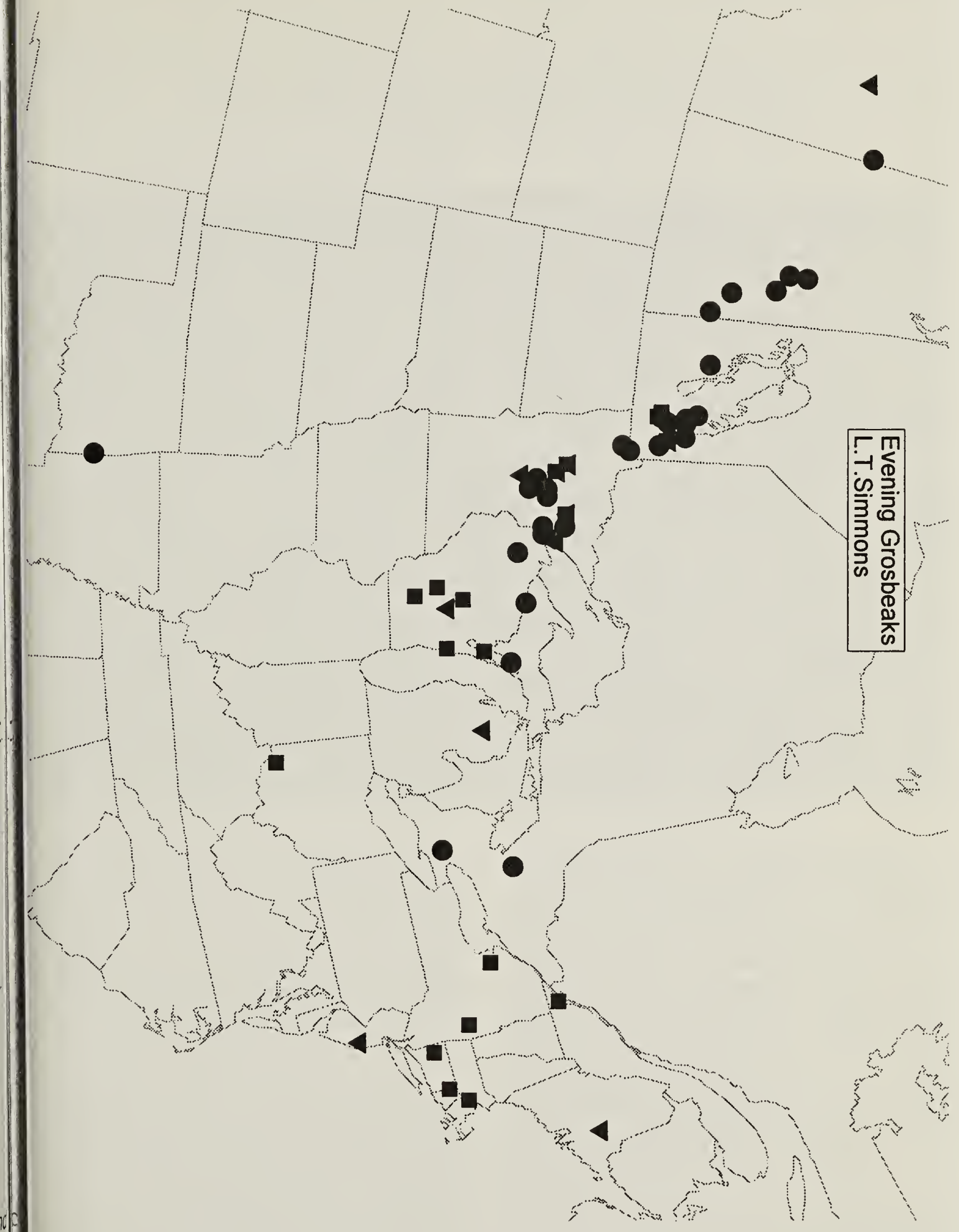

Figure 5. Evening Grosbeak encounters. Circles •, birds found dead; inverted triangles $\nabla$, grosbeaks banded in Winnipeg and recovered elsewhere; squares $\boldsymbol{\square}$, grosbeaks banded elsewhere and recovered in Winnipeg. Note the west to east direction of migration, typical of this species. 